\title{
Viral News on the Coronavirus: Does it Contribute to Health Communication?
}

\author{
Rachel E. Khan \\ University of the Philippines (Philippines)
}

From a century to a decade ago, the news media played a crucial role in providing the public with valuable information, especially during a crisis. However, the advent of social media has brought about a change in access and distribution of the news and this may have resulted in less effective health communication during this global coronavirus pandemic. These days, social media can have a greater public reach and therefore, be the best tool to disseminate information. At the same time, there is the question of whether the important or trivial information is being shared. The aim of this paper is to explore the role of social media in providing the public with important information during the height of the coronavirus pandemic. Using Great Britain as a case study, the research analysed the kind of content on the coronavirus that had gone viral in online news sources in the United Kingdom to determine whether the information that was being shared contributed or not to effective health communication.

Keywords: news, viral news, online media, journalism, crisis communication, coronavirus.

I ncreasingly, many people are turning to social media for their news and information. So much so that social media has become a primary source of information online. In fact, a study by Nic Newman of the Reuters Institute (2011: 14) showed that Facebook drove 56\% of the traffic to news media websites, through shared postings and online interactions. A similar study by the Pew Research Center found that social media users "now say each platform serves as a source for news about events and issues outside the realm of friends and family" (Shearer et al., 2015). The Pew research paper further noted: 
It added that three particular social media networks met these criteria, namely: Facebook, Twitter and Reddit (Shearer et al., 2015).

Similarly, Newman (2011: 15) quotes Facebook's journalist programme manager, Vadim Lavrusik as saying "They are discovering news via their friends -it finds them-". Wired magazine editor Chris Anderson was also quoted saying:

The news increasingly "comes to me" as more people choose social filters for their news rather than professional ones. We're tuning out television news, we're tuning out newspapers. And we still hear about the important stuff. ... I figure by the time something gets to me it's been vetted by those I trust. So the stupid stuff that doesn't matter is not going to get to me (Newman, 2011: 11).

This observation was concurred in a later study by Forbes magazine (Martin, 2018), which showed that $43 \%$ of the US population got their news from Facebook feeds.

This trend is changing the channels by which news is distributed (Alejandro, 2010). Journalistic institutions are losing their foothold as agenda-setters, i.e. telling audiences what they need to know and talk about rather than controlling what they think (Dearing and Rogers, 1988; McCombs and Shaw, 1972). If information regarding the coronavirus is seen as salient, then it would receive a more expansive coverage by the media and/or be increasing the topic of shared information on social media. Shearer (2018) observed:

When it comes specifically to news and information about government and politics, Facebook users are more likely to post and respond to content, while Twitter users are more likely to follow news organizations.

The challenge for any communicator —including those focusing on health — is getting important information to the public.

In the case of coronavirus, it could simply be the message of washing hands or the need for protective personal equipment for health workers. However, as experienced in recent years, journalists have raised the alarm over the continues decline of serious journalism, such as investigative reporting, due to downsizing of editorial staff and reduced financial support for in-depth reporting (Sullivan, 2015). The same has been said of science journalism, of which health reporting is a sub-topic (Cassany, Cortiñas, and Elduque, 2018).

Meanwhile, in the effort to compete for market share (Ingram, 2016; Holcomb, 2014), the news media are increasingly relying on prurient and populist coverage to maintain audience and to expand circulation. It is in this light that stories that have a propensity to be shared online and go viral have gained a foothold in mainstream news media content. With the development of social media and its increasing accessibility through mobile technology, audiences who were once mere content consumers have become their own agenda-setter as well.

During this period of the threat of the coronavirus, Sweney (2020) noted that in the United Kingdom: 
National and regional newspaper publishers are gaining record numbers of digital rea-

ders seeking to keep up to date about the pandemic.

However, the anarchic sphere of social media can become problematic for effective health communication. Even as online consumers continue to depend on traditional media for its news, the virality of information is not necessarily directly proportional to its importance.

With a great portion of the population relying on online information on the coronavirus, this research sought to examine the kind of information people were sharing online. Does social media, with particular emphasis on popular networks like Facebook, Twitter, Reddit and Pinterest, contribute to government's health communication? What kind of coronavirus-related information had gone viral?

\section{HEALTH COMMUNICATION AND VIRAL NEWS}

David Heymann, WHO's Assistant Director-General - Health Security had said that among the actions that are paramount to an effective health communication are:

1. The need to report promptly and openly cases of any disease with the potential for international spread;

2. The need for timely global alerts, supported by a responsible press and amplified by electronic communication; and,

3. The importance and challenge of risk communication strategies concerning new and emerging infectious diseases (Khan, 2013).

\section{Public Communication}

A virus, by its very definition, is communicable. Thus, to prevent a contagion and their potential to cause harm, information about it must be effectively communicated to both the medical stakeholders and the members of the community. As noted earlier, this is more efficiently done through the mass media, whose pervasiveness has a better audience reach than the official website of a government agency. According to media theorists James Dearing and Everett Rogers (1988) the agenda-setting theory implies that for health communication to be effective an issue or event must be seen as salient or newsworthy to the media. They also noted that there are two underlying assumptions to agenda-setting: media filters and shapes reality; and, by focusing on only a few issues, media can lead the public to perceive those issues as more important than others (Dearing and Rodgers, 1988).

The need for effective communication to the public is recognized in UK's Pandemic Influenza Communication Strategy 2012, drafted during the height of the H1N1 also known as the Swine Flu. On page 5 of the document, it specifically states: 
During a pandemic, the UK Government and the DAs will use a wide range of media to communicate information effectively to the public, to engage in discussion, and to identify areas of concern. Information may also be made available directly to the public through telephone helplines and other interactive channels.

Chief Medical Officers, and other trusted health professionals identified as the most effective spokespeople will issue regular press briefings. Key websites, social media sites and other information channels will be used to reach as wide an audience as possible.

The Department of Health will be the primary source of health-related messages and will work closely with the Cabinet Office, the Devolved Administrations, and other government departments. We will ensure that all direct communications to the public are made available.

This paper, however, posits that the availability of multiple digital platforms and possibly government's inability to maximize its potential as well as the user-led nature of social media, the ability to set the agenda has been watered down and the public's ability to set the agenda is elevated. Thereby, challenging efforts towards effective health communication by drowning out useful information with trivialities at best or creating an infodemic of unreliable or panic-inducing information at worst.

\section{Viral NeWS}

Etymologically, virus comes from the Latin word "viscum" meaning venom or poison. Viral, on the other hand, was a term that evolved in the 1940s to mean "disease caused by a virus". ${ }^{1}$ The idea that information could become virulent is attributed to Media theorist Marshal McLuhan in his Understanding Media (1964: $14,193)$; while the term viral for digital content is attributed to writer Douglas Rushkoff (Jenkins, Ford, and Green, 2013).

For the purposes of this paper, we defined Viral News as:

networked news stories that spread online mostly through social media in a much faster and wider manner than other news stories (Ahmed, 2019).

Konnikova (2014) noted that online virality is similar to effective word-of-mouth (WOM) messages that can be traced back to Aristotle's key to effective communication, i.e. the focus on the ethos, pathos and logos.

Similarly, WOM studies by Allsop, Bassett and Hoskins (2007) showed that messages most shared were arousing and emotional. This was concurred in a more recent study by Berger and Milkman (2011: 10), which noted:

1 <https://www.merriam-webster.com/dictionary/virus>. 
Online content that evoked high-arousal emotions were more viral, regardless of whether

those emotions were of a positive (i.e., awe) or negative (i.e., anger or anxiety) nature.

They also noted that people share stories, news and information that were thought to contain useful information. Moreover, Trusov, Bucklin, and Pauwels (2009: 90) noted:

We find that WOM referrals strongly affect new customer acquisitions and have significantly longer carryover than traditional forms of marketing used by the firm.

If this was applied to health communication on the coronavirus, this would have translated to more effective messaging in terms of healthy personal practices needed to combat the virus.

On the other hand, content that evokes low-arousal, or "deactivating" emotions, such as sadness, were less viral (Berger and Milkman, 2011: 11). Moreover, Sampson (2012: 157) argued:

what spreads can either be fearful or joyful which are "adaptive" contagions that trigger empathic transmissions of affect and imitative entrainment.

He cited repeated clips from 9/11 terror attack as an example of terror inciting contagion; and, election of US President Barack Obama as an example of mass empathy becoming the means of virality.

Congruently, Ansgard Heinrich (2012) noted that the internet age decentralized news and made it nonlinear. The news media, he claimed, has lost its control over a formerly strictly regulated sphere of information exchange. He also noted:

The task for journalistic organizations now is to figure out how to include the many traditional and alternative information nodes in their everyday work (2012: 63).

This concurs with Levinson's argument in his book, New New Media? (2009: 16), wherein he observed that social media users in new media have the "control of when and where to get text, sound and audio-visual content".

Apart from making news go viral, Facebook is also indicative of how well a news item is received or thought important because of the user's ability to "like" and "share" a post. Likes and shares along with emoticons that show whether an audience member was happy, sad or angry about a 'post' serve as popularity cues. This can help the researcher determine the attention received by a news item as well as the relevance the audience attached to the information contained therein (Porten-Cheé et al., 2018).

\section{THE UNITED KINGDOM AS CASE STUDY}

The first cases of COVID-19 in the United Kingdom (UK) were detected in late January and transmission within the country was detected in the following 
month. The BBC reported that this first British citizen had 'caught the virus at a conference in Singapore and then travelled to a ski resort in France' ("Coronavirus: UK", 2020 Feb 10). The Secretary of State for Health and Social Care Matt Hancock issued the "Health Protection Coronavirus Regulations 2020 statutory instrument" in February even as the government, through the National Health Service (NHS) launched an information campaign on COVID-19. ${ }^{2}$ Meanwhile, the news media continued to report on the virus and the escalating COVID-19 cases in Italy, Spain and France.

On 11 March 2020, the World Health Organization (WHO) declared the severe acute respiratory syndrome coronavirus (SARS-CoV2) a global pandemic (Ghebreyesus, 2020). This announcement came exactly two months after WHO had admitted that they had identified a novel virus from Wuhan, China in December 2019. Meanwhile, the Coronavirus Disease 2019 also known as COVID-19 had begun to spread to 18 other nations outside China, particularly the population of Italy and Iran, which had death tolls in catastrophic numbers.

At the beginning of March, UK Prime Minister Boris Johnson announced that his government was adopting a national plan against COVID-19 but ended his statement with:

At this stage, and with the exception of all of the points I have just mentioned, I want to stress that for the vast majority of the people of this country, we should be going about our business as usual.

However, two weeks later, on March 23, following the passage of the Coronavirus Act 2020 (Hancock, 2020) and the Health Protection Regulations 2020, Johnson announced the enforcement of a lockdown to protect the National Health System.

As of mid-June 2020, the UK had 291,409 confirmed COVID-positive cases and 41,279 COVID-related deaths. ${ }^{3}$ Top UK government officials were not exempt from COVID exposure. In fact, Johnson and Hancock announced that they were COVID-positive in late March but were well into recovery by the first week of April 2020 (Proctor and Weaver, 2020).

\section{METHODOLOGY}

According to estimates made by statista.com, Facebook users in the United Kingdom increased from an average of 36 million in 2019 to 44 million in the first three months of 2020 even as Internet penetration was pegged at $94 \%$ of the population (Johnson, 2020). Meanwhile, the latest Global Digital Report of

$2<$ https://www.medscape.com/viewarticle/924664>.

$3<$ https://www.gov.uk/guidance/coronavirus-covid-19-information-for-the-public>. 
WeAreSocial.com noted that 78\% of Internet users in the UK were active on Facebook in 2019; 46\% were active on Twitter; 27 percent on Pinterest; and, 14\% on Reddit (Dubras, 2019).

To determine if the abovementioned information campaign on COVID-19 were in people's consciousness, the researcher examined the trending news on UK media on the coronavirus from January 2020 to June 2020 in order to determine the extent by which the virus was being discussed on social media.

While all the articles on the coronavirus from January to June 2020 were tracked, the research focused only on the top 100 news items for the content analysis. The articles were identified using the web scraping technology and analytical tools of BuzzSumoTM and CrowdTangleTM; and, ranked based on their audience response as seen in the measurable number of "total engagements" in four main social media applications: Facebook, Twitter, Pinterest and Reddit. For the purposes of this paper, the researcher defined 'Total engagement' as the sum total of shares, likes (and other reactions), retweets, clicks and comments to a post from UK media institutions and/or a UK government link.

The researcher found that the article, "Florida beaches to start reopening this evening" (Griffith and Tanno, April 2020) came in the first place and had a "total engagement" rate of 5.3 million on Facebook; 7,400 on Twitter; 20 on Pinterest and 173 on Reddit. In the 100th place was an article on Italy, "Further 793 people die of coronavirus in the past 24 hours" (Carr, 2020) published in the Daily had a "total engagement rate" of 652,300 from Facebook, 535 retweets, 21 shares on Pinterest and four on Reddit. Only one article from a government website entered the top 100, i.e. "Coronavirus (COVID-19) what you need to do" from www.gov.uk with a "total engagement" rate of 723,300 on Facebook; 12,500 on Twitter; 43 on Pinterest and 166 on Reddit. It is interesting to note that among the top sharer of this government-produced article were the Twitter accounts of the Prime Minister Johnson and Health Minister Hancock under \#Staysafe.

The researcher also analysed the content of the coronavirus news articles shared on these social media networks to determine if they contributed to the public's knowledge of the Health Department's information campaign and what they needed to do to protect themselves against the deadly virus.

\section{FINDINGS}

Despite the pandemic, the researcher found that only about a third of the top viral posts on Facebook from January to June 2020 was about or related to coronavirus disease. Figure 1 shows the trending themes of Facebook posts, which showed that the social media network continued to trend in human interest stories, which are usually inspirational in nature, at $21 \%$ and stories about animals (both pets and in the wild) at 19\%.

However, trending posts on the coronavirus were still substantial. From January to June 2020, a total of 268,032 news articles on the coronavirus were tracked on the four social media networks. The impact of these articles multiplied further on social media as they yielded a total of 546,636,252 interactions over the same period. 
Figure 1. Overall Trending Themes on Facebook, January to June 2020

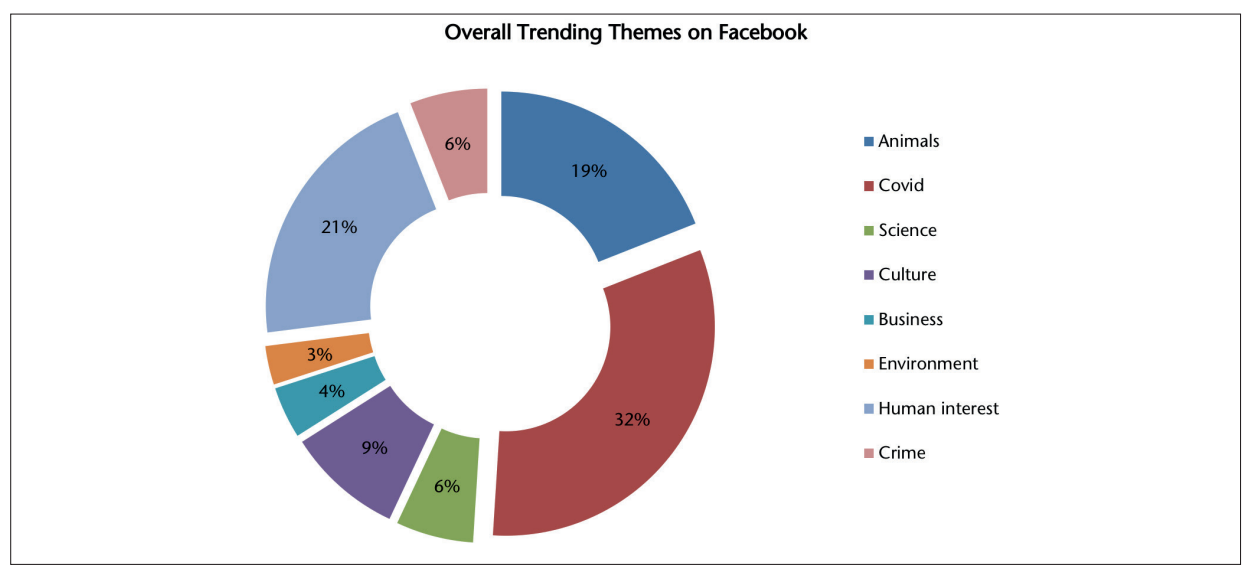

Source: Content analysis by the author based on the top 100 trending posts on Facebook, CrowdTangle.

As expected, news about the coronavirus dominated the social media in the first three months of 2020; then, showed a steady rate of decline from April to June (see Figure 2). Understandably, the news articles and their engagements peaked in March, the month that the World Health Organization formally declared the coronavirus as a pandemic and the same month that British Prime Minister Boris Johnson declared a lockdown to flatten the contagion curve ("Coronavirus: Strict", March 2020). Below, Figure 2 shows the monthly distribution of articles and Figure 3 their total engagements.

Figure 2. Total number of articles on coronavirus per month

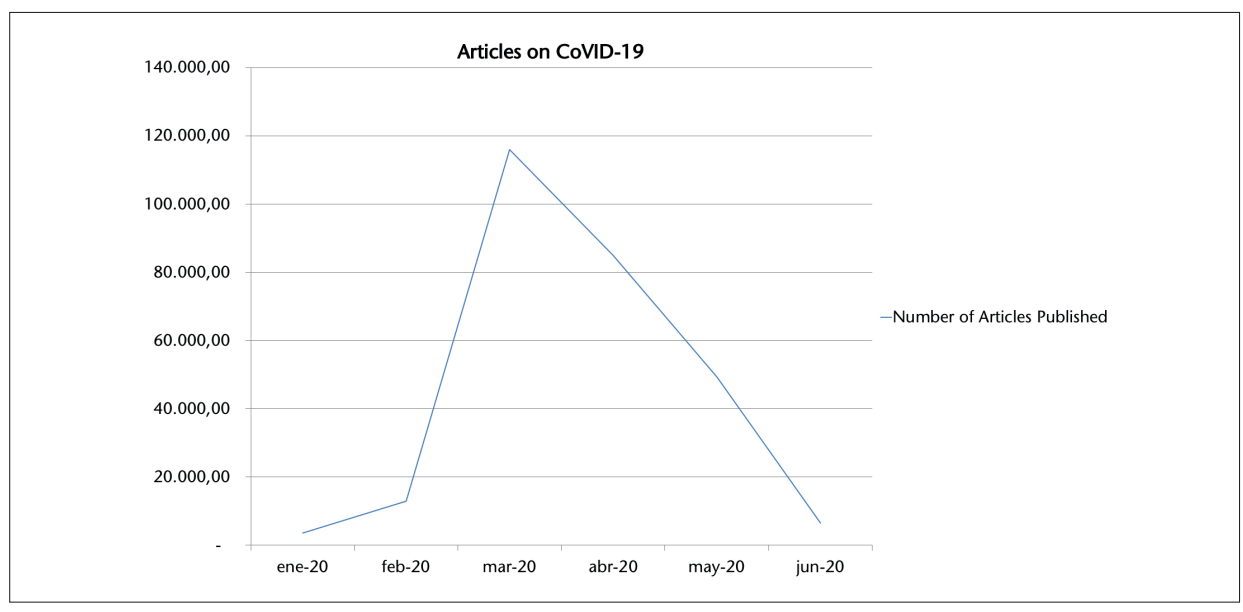


Figure 3. Total engagements of articles on coronavirus per month

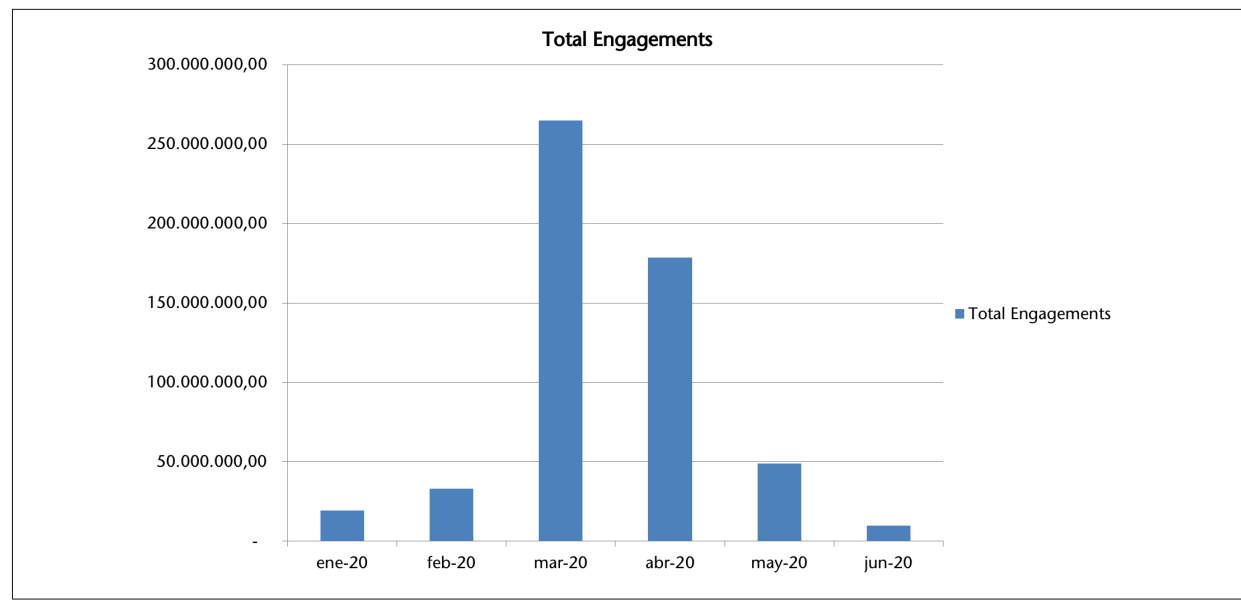

Source: Analyzed by the author using BuzzSumo, June 2020.

As noted earlier, 78\% of the British Internet-users are on Facebook. Thus, it is not surprising that of the four social media networks, Facebook was the most engaged as seen below in Figure 4.

Figure 4. Total engagements per social media network

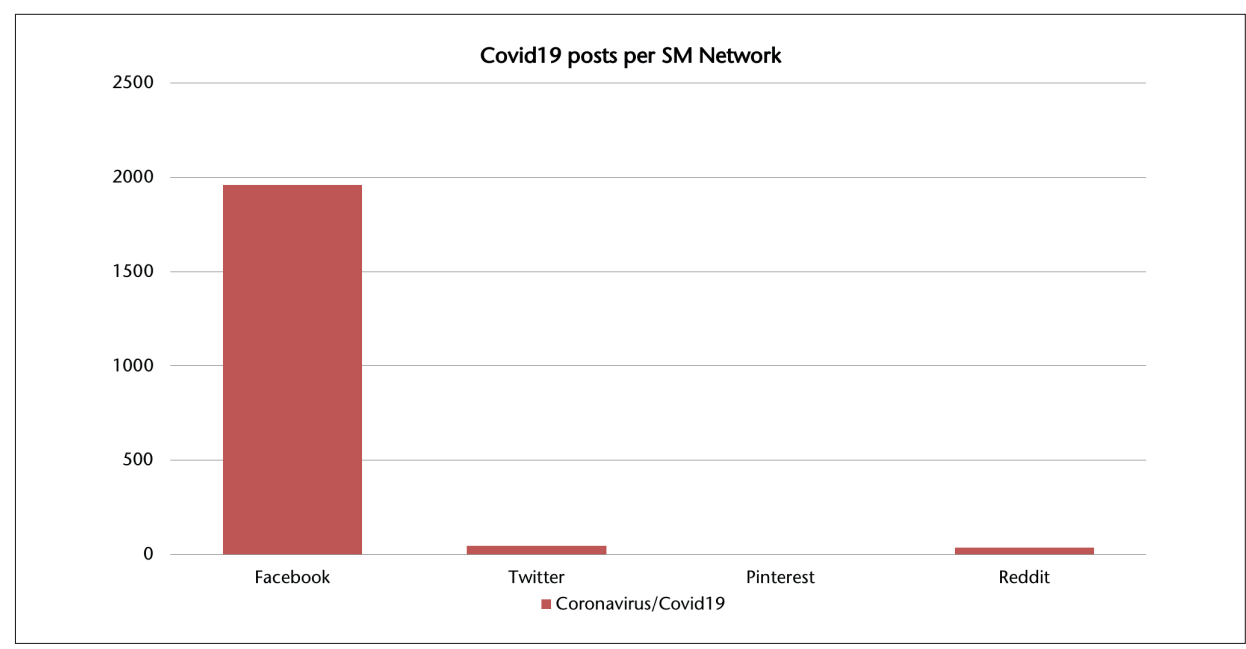

Source: BuzzSumoTM.

Meanwhile, the top 100 trending news articles were traced to ten British media institutions with the Daily Mail and the British Broadcasting Corporation (BBC) taking the lead with a total engagement rate of 178.6 million and 86.8 million, 
58 respectively (see Figure 5) for all its web content. The other media outlets rated as follows: The Independent, 79.3 million; Daily Mirror, 30.7 million; The Sun, 29.2 million; Metro 27.5 million; Daily Express, 13.3 million; The Telegraph, 10.1 million; The Daily Star, 6.9 million; and, The Standard, 6.9 million. As noted earlier, the gov.uk site had one article on coronavirus in the top 100. The government site recorded a total engagement of 5.1 million.

It may be worth mentioning that the two top engaged sites are also among the leaders in their own respective media industries. The Daily Mail was founded in 1826, it is a middle-market tabloid, ranked in the third place4 in terms of audience share in the print media category. It is privately-owned by the Daily Mail General Trust, of which the Viscount Jonathan Harmsworth, whose ancestors established the paper, still holds controlling shares. While, the British Broadcasting Corporation (BBC) is the oldest national public broadcaster in the world. Based on the latest statistics (2018), it holds $30.9 \%$ of broadcast audience share in the United Kingdom. ${ }^{4}$

Other sites that were studied but did not have any entries in the top 100 articles include: The Times of London, Manchester Evening News, Birmingham Mail, The Daily Record, The Scottish Sun and the Daily Post.

\section{Figure 5. Total engagement per British Media Outlet in the Top 100 trending news}

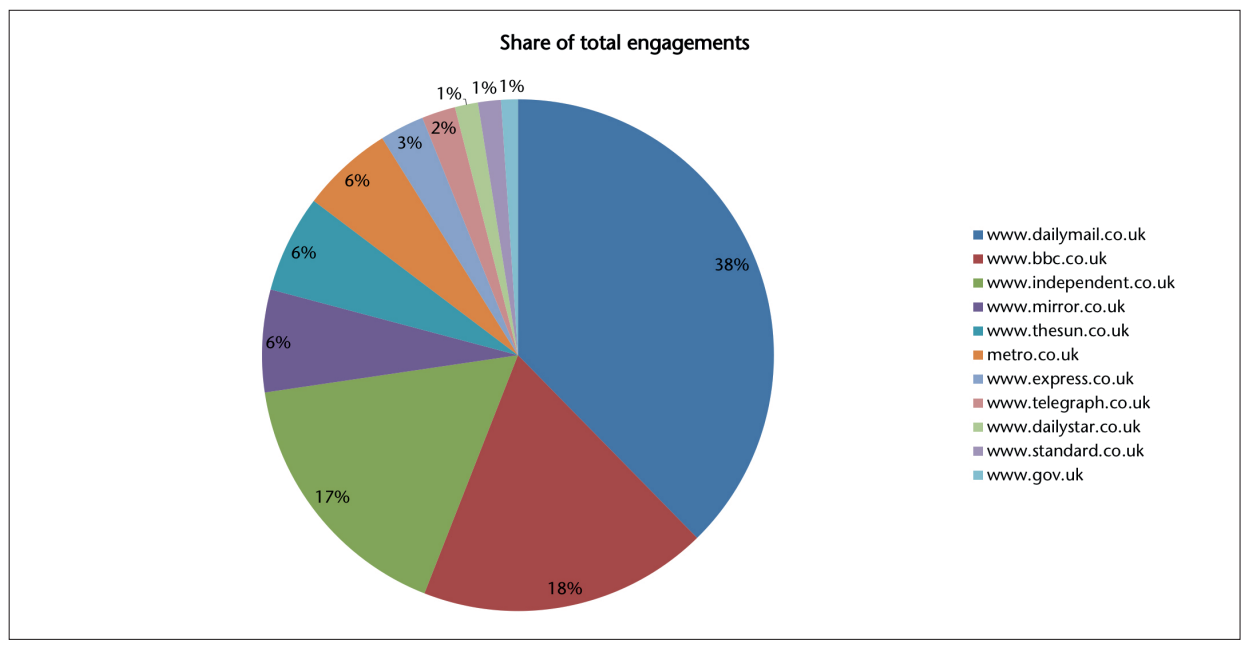

Source: Analyzed by the author using BuzzSumo, June 2020.

Applying a qualitative content analysis method to the top 100 trending news, the researcher identified and classified the type of news was being shared on 
social media and if it had any content that was related to the UK government's official COVID-19 communication. To determine the relationship of the article to communication efforts in the fight against COVID-19, the researcher classified the news items into the following categories:

- COVID-19 information - Articles that give readers advice or instructions on what to do to stay safe from the deadly virus. Stories that instruct about healthy habits, what to do during the lockdown; government announcements; and other health related information fall into this category;

- Morbidities - Articles that focus on reporting those who were diagnosed as COVID-19 positive and/or those who have either survived or died from the disease;

- Science - Articles that give readers updates on laboratory tests in the search for detection and cures;

- COVID-19 abroad - Articles that inform readers about the status of the deadly virus outside the UK except China;

- US News - Articles that inform readers about the status of the deadly virus in the United States;

- China - Articles that inform readers about the coronavirus from the original source of the virus;

- Culture - Articles that inform readers about the effects of coronavirus on local culture, including the entertainment industry;

- Business - Articles that inform readers about the effects of coronavirus on business and the economy;

- Others - Articles that do not fit in the abovementioned categories.

Figure 6. Trending themes of Top 100 trending coronavirus stories in social media in the UK

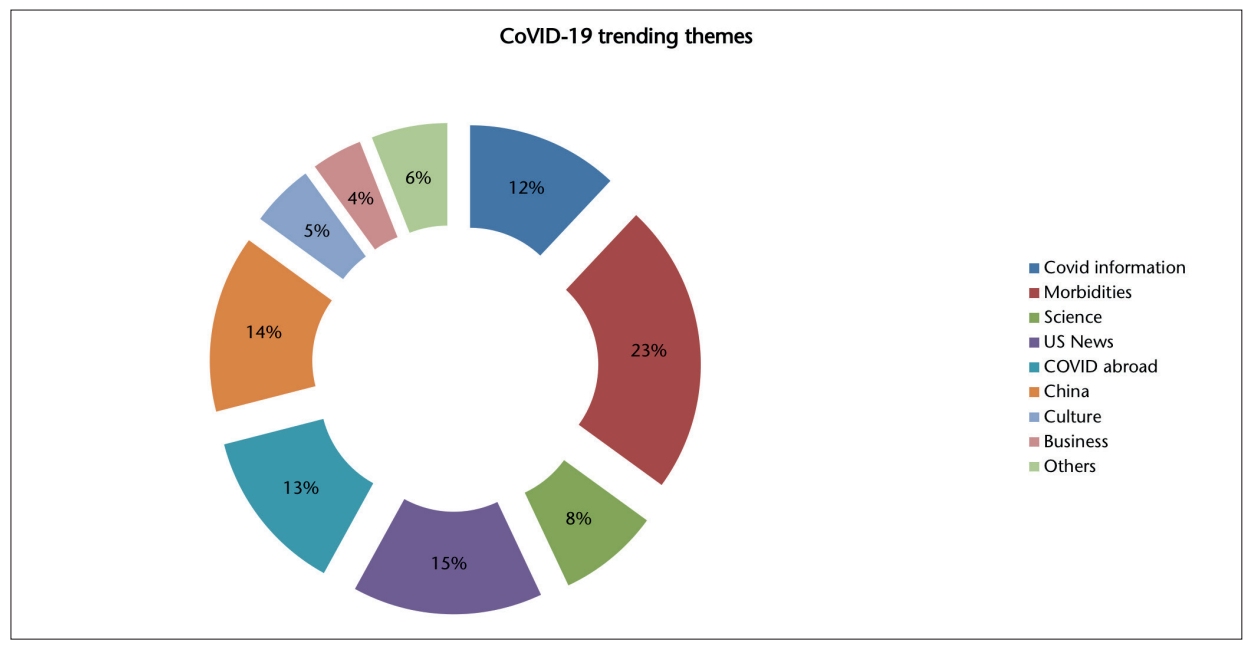


Figure 6 shows the result of the content analysis. The researcher found that a big chunk of the pie comprised of news regarding COVID-19, especially about those contracting the virus and its subsequent related deaths in the UK.

As gleaned from Figure 6, the category dubbed as Morbidities garnered the highest share of stories at 23\%. These reported mostly about British citizens who were diagnosed with COVID-19, including the Prime Minister Johnson ("Boris Johnson admitted...", April 2020), Health Minister Nadine Dorries ("Health minister...", April 2020) and Prince Charles ("Prince Charles tests," March 2020). It also reported the deaths due to the virus in the UK. Only two out of the 23 trending stories reported about patients recovering from the disease.

On the other hand, the category labelled US news ranked the second highest at $15 \%$. This category included stories such as a Daily Mail reports on "Donald Trump suggests bizarre treatments" (Earle, April 2020) and the article with the highest engagement at 5.2 million, "Florida beaches to start reopening this evening" (Griffith and Tanno, April 2020).

Notably, the category COVID-19 Information, which contains news related to government announcements, policies and calls to action regarding the coronavirus as well as precautionary measures that citizens should take to avoid the illness, garnered only $12 \%$ of total, lower that the percentage of news for COVID-19 abroad (13\%) and China (14\%). Included in this category was Queen Elizabeth II's rare public address ("Queen tells UK 'we will succeed", April 2020); the World Health Organization announcement of the pandemic (Ghebreyesus, 2020); "Public urged to follow 'mission-critical' rules" (Hancock, 2020); and, "Coronavirus: What You Need To Do" (January 2020).

It was also noted that in the category on China that most of the articles are dated during the early days of the onset of the disease from January to the first week of March. Sample articles include the Daily Mail story on "China's coronavirus did come from bats" (Blanchard, February 2020) had a high engagement rate of 1.8 million as well as The Sun's story on "Cats and dogs thrown from tower blocks in China after fake news rumours animals are causing the virus" (Lockett, January 2020).

This was followed by news from other countries apart from the US and China ('COVID Abroad') at 13\%. News items in this category range from serious articles such as "More than 2,600 medical workers have been infected in Italy" (Stickings, March 2020) to trivial articles such as "Deserted Italian street rings out with song as people lean out of windows and sing together" (Ng, March 2020).

While the rest of the categories are self-explanatory, the one labelled 'Others' really could not be included in the other sets. Only four stories fall under this category, including Dawn Neesom's commentary on "The human race is in grave danger of stupidity, not coronavirus" (Neesom, 2020) and "Lions nap on road during South African lockdown" (April 2020).

Furthermore, a cursory examination of the online sites of the top trending news showed that they were not remiss in sharing NHS videos and information about the Wuhan coronavirus. However, these registered very low engagements. For example a BBC news item entitled, "The UK Health Secretary Matt Hancock has announced measures to ensure the public are protected from the transmis- 
sion of the coronavirus," had a total engagement of 22,000 as compared to the earlier mentioned statistic of 5.2 million for the re-opening of the beaches in Florida.

\section{CONCLUSION}

Even as news on the coronavirus dominated the news, in the case of the UK experience, the social media audience were not too engaged with the official health information news and its official channels. The study found that official channels such as the website and social media accounts of the National Health Service rendering their so-called campaign ineffective and practically absent in terms of the media and the public agenda.

In fact, coronavirus information from UK's government websites, such as the NHS website $<$ nhs.uk $>$, the National Institute of Health and Care Excellence $<$ nice.org.uk $>$ and National Institute for Health Research $<$ nihr.ac.uk $>$, showed very low interactions and had statistics that were low compared to the top 100 trending news. For example, the NHS Easter message encouraging people to stay home, ${ }^{5}$ only had 109,800 views and a total engagement of a mere 2,081.

Also, most British private sector media outlets focused on their own reporting on COVID-19 and not the NHS material. Thus, most of the news focused on the daily issues and events rather than health information. Even the BBC uploaded the NHS information material on their website only for a short time. For example the NHS video entitled, 'Stay home, save lives'. The UK government's latest advice on coronavirus is asking everyone to stay home, to "help protect the NHS," is no longer on the BBC website, although based on CrowdTangle, it was viewed 2.3 million times and had a total engagement of 28,103.

Thus, one conclusion that can be derived from this study is that the UK's Pandemic Influenza Communication Strategy 2012 as well as the current NHS Communication - which advises that the Department of Health will be the primary source of health-related messages and that the Chief Medical Officers will be effective spokespersons - fell short. Primarily, they failed to consider communication strategies through the mass media and social media. This is evinced by the fact that the only time Health Secretary of State Matt Hancock and Health Minister Nadine Dorries were mentioned in the top 100 trending news was when they contracted the virus themselves.

On the bright side, false information or fake news regarding coronavirus cures were not in the top 100 viral news. In fact, one of the news items that did go viral was an announcement by the makers of Lysol debunking President Trump's wild COVID-related statement about digesting disinfectants ("Lysol urges people...", April 2020). This news item has a total engagement of 1.3 million.

$5<$ <ttps://www.facebook.com/NHSwebsite/videos/155033885852585/>. 
On the other hand, it should be noted that the sole <gov.uk> how-to article that made it to the top 100 primarily because it was retweeted by UK Prime Minister Boris Johnson on his personal account <@borisjohnson>, with a following of 2.8 million and a retweet average of $45 \%$ as well as the official Prime Minister account $<@ 10$ downingstreet $>$, with a following of 5.8 million and a retweet average of 23\%. It was also retweeted by Larry the Cat (@number10cat), the 12-year old tabby, unofficially the "Chief Mouser of the UK Cabinet", who has a following of 386,000.

Thus, a second conclusion that can be derived from this study is that government must identify social media influencers who will repost and retweet government health communication so that these messages become viral. The trick, however, is to be able to identify the proper influencer. After all, who would have guessed that Larry the Cat, would come in as a third placer to the official UK Prime Minister Twitter account.

Finally, the research showed that viral news continued to behave in the same manner as it did prior to the pandemic. The research findings showed that despite the urgency and importance of the coronavirus information, trending news continued to focus on the trivial such as animal antics and beach openings.

Viral news regarding the coronavirus peaked during the lockdown but immediately waned afterwards. As noted by the findings, coronavirus news only occupied a third of viral news from January to June 2020, peaked in March and started its decline in mid-April. Useful information about the virus were drowned out by trivialities such as a man catches coronavirus while in Italy with his mistress (Moyes, March 2020) and Italians singing during lockdown (Ng, March 2020).

Thus, the study concludes that despite the scale of the COVID-19 did not translate to an increase in health communication in viral posts. Trending news maintained the overall characteristics of viral news prior to the pandemic, i.e. arousing and emotional, regardless of whether they were positive or negative in content (Allsop, Bassett, and Hoskins, 2007; Berger and Milkman, 2011).

Rachel E. Khan (rekhan2@up.edu.ph), DPA, is a professor of Journalism and Associate Dean at the University of the Philippine College of Mass Communication. She is concurrently Board Chair of the Asian Congress for Media and Communication, an Asia-wide organization of mass media academics and professionals. She holds a M.S. Journalism with a New Media concentration from the Columbia University, New York under the Fulbright program, and a doctorate in Public Administration from the University of the Philippines. She has authored several books and has given public lectures at the Central European University, Chulalongkorn University and Universitas Gadjah Mada on Media Literacy and the Internet as a Mass Medium. 


\section{References}

UK GOVERNMENT (2020, January 25). "Coronavirus: What You Need To Do". UK Government. Available at: <http://www.gov.uk/ coronavirus $>$. Accessed 5 April 2020.

BBC. (2020, March 24). "Coronavirus: Strict New Curbs on Life". BBC. Available at: <https://www.bbc.com/news/uk-52012432>. Accessed 20 April 2020.

-. (2020, April 1). "Coronavirus: Charles Speaks Following Virus Diagnosis". BBC. Available at: <https://www.bbc.com/news/ av/uk-52124694/coronavirus-charles-speaksfollowing-virus-diagnosis>. Accessed 5 April 2020.

—. (2020, April 5). "Queen Tells UK 'We Will Succeed"'. BBC. Available at: <https:// www.bbc.com/news/uk-52176222>. Accessed 10 April 2020.

—. (2020, April 6). "Coronavirus: Boris Johnson Admitted to Hospital over Virus Symptoms". BBC. Available at: <https://www.bbc. com/news/uk-52177125>. Accessed 5 April 2020 .

-. (2020, April 6). "Coronavirus: Boris Johnson Admitted to Hospital over Virus Symptoms". BBC. Available at: <https://www.bbc. com/news/uk-52177125>. Accessed 5 April 2020.

-. (2020, April 16). "Lions Nap on Road During South African Lockdown". BBC. Available at: <https://www.bbc.com/news/worldafrica-52314282>. Accessed 5 April 2020.

-. (2020, April 24). "Lysol Urges People not To Inject Disinfectants to Treat COVID-19". Daily Mail. Available at: <https:// www.dailymail.co.uk/news/article-8253387/ Lysol-maker-urges-people-not-injectdisinfectants-Trump-remarks.html>. Accessed 1 June 2020 .

Ahmed, A. (2019). "Viral News on Social Media," Digital Journalism, 7 (1), pp. 63-79.

Alejandro, J. (2010). "Journalism in the Age of Social Media". Reuters Institute for the Study of Journalism Reports. Available at: <https://
www.mediaforum.md/upload/Journalism $\% 20$ in $\% 20$ the $\% 20$ Age $\% 20$ of $\% 20$ Social \%20Media.pdf>. Accessed 15 March 2020.

Allsop, D.; Bassett, B., and Hoskins, J. (2007). "Word-of-Mouth Research: Principles and Applications". Journal of Advertising Research, 47 (4), pp. 398-411.

Berger, J. and Milkman, K. (2011). "What Makes Online Content Viral?". Journal of Marketing Research, 49(2), pp. 192-205.

Blanchard, S. (2020, February 3). "China's Coronavirus Did Come from Bats”. Daily Mail. Available at: < https://www.dailymail.co.uk/ health/article-7960423/The-Latest-Shanghaiindex-drops-8-virus-outbreak-grows.html>. Accessed 15 March 2020.

Carr, J. (2020, March 21). "Further 793 People Die of Coronavirus in the Past 24 Hours". Daily Mail. Available at: <https://www.dailymail.co.uk/news/article-8138183/Further793-people-die-coronavirus-Italy-past24-hours.html>. Accessed 15 March 2020.

Cassany, R.; Cortiñas, S., and Elduque, A. (2018). "Comunicar la Ciencia: El perfil del periodista científico en España". Comunicar, 55 (26), pp. 9-18.

Dearing, J. and Rogers, E. (1988). "AgendaSetting Research: Where Has it Been, Where Is it Going?". Communication Yearbook, 11, pp. 555-594.

Dubras, R. (2019). "Digital in the UK: Data and Learnings for 2019". We Are Social. Available at: <https://wearesocial.com/ uk/blog/2019/03/digital-in-the-uk-data-andlearnings-for-2019>. Accessed 10 April 2020.

Earle, G. (2020, April). "Donald Trump Suggest Injecting the Body with Disinfectants". Daily Mail. Available at: <https:// www.dailymail.co.uk/news/article-8251605/ Donald-Trump-suggests-bizarre-treatmentscoronavirus-including-injections.html>. Accessed 26 April 2020.

Ghebreyesus, T. (2020, March 11). "COVID-19 Media Briefing". World Health Orga- 
nization. Available at: <https://www.who.int/ $\mathrm{dg} /$ speeches/detail/who-director-general-sopening-remarks-at-the-media-briefing-oncovid-19---11-march-2020>. Accessed 1 April 2020 .

Griffith, K and Tanno, S. (2020, April). "Florida Beaches To Start Reopening this Evening". Daily Mail. Available at: <https:// www.dailymail.co.uk/news/article-8229933/ Beaches-Florida-start-reopening-EVENING. html>. Accessed 26 April 2020.

Hancock, M. (2020, April 5). "Public Urged To Follow 'Mission-Critical' Rules". BBC. Available at: <https://www.bbc.com/news/uk52172035>. Accessed 15 April 2020.

Hancock, M. and Bethell, J. (2020). An Act to Make Provisions in Connection with Coronavirus and for Connected Purposes. UK Public General Acts. Available at: <http://www.legislation. gov.uk/ukpga/2020/7/contents $>$. Accessed 5 April 2020.

Heinrich, A. (2012). Network Journalism. New York: Routledge.

Hilton, S. and Smith, E. (2010). "Public Views of the UK Media and Government Reaction to the 2009 Swine Flu Pandemic". BMC Public Health, 10 (697). DOI: <https://doi. org/10.1186/1471-2458-10-697>.

Holcomb, J. (2014, April). "News Revenue Declines Despite Growth from New Sources". Pew Research Center. Available at: <http:// www.pewresearch.org/fact-tank/2014/04/03/ news-revenue-declines-despite-growth-fromnew-sources/>. Accessed 20 April 2020.

Ingram, M. (2016). "Newspaper Giants Fight for Market Share". Fortune. Available at: $<$ https://fortune.com/2016/05/20/gannett-vstribune/>. Accessed 15 March 2020.

Jenkins, H.; Ford S., and Green, J. (2013). Spreadable Media: Creating Value and Meaning in a Networked Culture. New York: New York University Press.

Johnson, J. (2020). “Total number of Internet users in the United Kingdom". Available at: <https://www.statista.com/statistics/507399/ total-number-of-internet-users-in-the-united- kingdom-uk-by-data-provider/>. Accessed 20 April 2020.

Khan, R. E. (2013). "10 Years after SARS: Have Health Communicators Learnt the Lessons?". Media Asia, 40 (1), pp. 4-10.

Konnikova, M. (2014). "The Six Things that Make Stories Go Viral". The NewYorker. Available at: <https://www.newyorker.com/ tech/annals-of-technology/the-six-thingsthat-make-stories-go-viral-will-amaze-andmaybe-infuriate-you>. Accessed 15 March 2020.

Levinson, P. (2009). "Why 'New New' Media?". In: New New Media. New York: Allyn \& Bacon, pp. 1-16.

Lockett, J. (2020, January 31). “Cats and Dogs Thrown from Tower Blocks in China after Fake News Rumours Animals Are Causing the Virus". The Sun. Available at: <https://www. thesun.co.uk/news/10863349/coronaviruscats-and-dogs-thrown-to-death/>. Accessed 15 April 2020.

Martin, N. (2018). "How Social Media Has Changed How We Consume the News". Forbes. Available at: <https://www.forbes. com/sites/nicolemartin1/2018/11/30/howsocial-media-has-changed-how-we-consumenews/\#121d347e3c3c>. Accessed 10 April 2020.

McCombs, M. and Shaw, D. (1972). "The Agenda Setting Function of Mass Media". Public Opinion Quarterly, 36 (2), pp. 176-187.

McLuhan, M. (1964). Understanding Media: The Extensions of Man. USA: McGraw-Hill.

Moyes, S. (2020, March 17). "Cheating Husband Catches Coronavirus on Secret a Trip to Italy". The Sun. Available at: <https:// www.thesun.co.uk/news/11189716/cheatinghusband-catches-coronavirus-secret-trip-italymistress/>. Accessed 5 April 2020.

Neesom, D. (2020, March 10). "The Human Race Is in Grave Danger of Stupidity, not Coronavirus". Daily Star. Available at: <https:// www.dailystar.co.uk/news/latest-news/dawnneesom-the-human-race-21669145>. Accessed 5 April 2020. 
Newman, N. (2011). "Mainstream Media and the Distribution of News in the Age of Social Media". Reuters Institute for the Study of Journalism Reports. Available at: <https://ora. ox.ac.uk/objects/uuid:94164da6-9150-49388996-badfdef6b507>. Accessed 15 March 2020.

Ng, K. (2020, March 13). "Deserted Italian Streets Ring out in Song As People Lean out of Windows to Sing Together During Lockdown". The Independent. Available at: <https:// www.independent.co.uk/news/world/europe/ coronavirus-italy-siena-song-canto-dellaverbena-video-lockdown-a9399176.html>. Accessed 5 April 2020.

Porten-Cheé, P.; Haßler, P.; Eilders, J. C., and Maurer, M. (2018). "Popularity Cues in Online Media: Theoretical and Methodological Perspectives". Studies in Communication and Media, 7 (2), pp. 208-230.

Proctor, K. and Weaver, M. (2020, March 27). "Boris Johnson and Matt Hancock in Self-Isolation". The Guardian. Available at: <https://www. theguardian.com/world/2020/mar/27/ukprime-minister-boris-johnson-tests-positivefor-coronavirus>. Accessed 10 April 2020.

Sampson, T. (2012). Virality: Contagion Theory in the Age of Networks. Minneapolis: University of Minnesota Press.

Semir, V. de (1996). "What is Newsworthy?" The Lancet, 347(9009), pp. 1163-1166.

Shearer, E.; Barthell, M.; Gottfried, J., and Mitchell, A. (2015). "The Evolving Role of News on Twitter and Facebook". Pew Center Research. Available at: <https://www.journalism. org/2015/07/14/the-evolving-role-of-news- on-twitter-and-facebook/>. Accessed 15 March 2020.

Shearer, E. (2018). "Social Media Outpaces Print Newspapers in the US As a News Source". Pew Center Research. Pew Center Research. Available at: <https://www.pewresearch. org/fact-tank/2018/12/10/social-mediaoutpaces-print-newspapers-in-the-u-s-as-anews-source/>. Accessed 15 March 2020.

Silverman, C. (2015). "Lies, Damn Lies and Viral Content: How News Websites Spread (and Debunk) Online Rumors, Unverified Claims and Misinformation". Columbia Journalism Review. Available at: <https://www. cjr.org/tow_center_reports/craig_silverman lies_damn_lies_viral_content.php $>$. Accessed 15 March 2020.

Sullivan, M. (2015). "The Search for Local Investigative's Future". The New York Times. Available at: < https://www.nytimes. com/2015/12/06/public-editor/margaretsullivan-new-york-times-public-editor.html>. Accessed 15 March 2020.

Sweney, M. (2020). "Newspapers To Lose $£ 50$ million in Online Ads As Firms Use Coronavirus Black List". The Guardian. Available at: $<$ https://www.theguardian.com/media/2020/ apr/01/newspapers-to-lose-50m-in-onlineads-as-firms-use-coronavirus-blacklist $>$. Accessed 15 April 2020.

Trusov, M.; Bucklin, R. E., and Pauwels, K. (2009). "Effects of Word-of-Mouth versus Traditional Marketing: Findings from an Internet Social Networking Site". Journal of Marketing, 73(5), pp. 90-102. 
